American Journal of Applied Sciences 9 (7): 1085-1090, 2012

ISSN 1546-9239

(C) 2012 Science Publications

\title{
Home Stay Accommodation for Tourism Development in East Coast Economic Region
}

\author{
${ }^{1} \mathrm{Md}$. Anowar Hossain Bhuiyan, ${ }^{1}$ Chamhuri Siwar, \\ ${ }^{1}$ Shaharuddin Mohamad Ismail and ${ }^{2}$ Rabiul Islam \\ ${ }^{1}$ Institute for Environment and Development (LESTARI), \\ University Kebangsaan Malaysia, 43600 UKM, Bangi, Darul Ehsan, Selangor, Malaysia \\ ${ }^{2}$ Department of Economics and Agribusiness Management, School of Economics, \\ Finance and Banking, College of Business, \\ Universiti Utara Malaysia, 06010 Sintok, Kedah Darul Aman, Malaysia
}

\begin{abstract}
Problem statement: Home stay program provided tourists multi ethnic life condition with cultural experiences and economic well beings for the local people. Malaysian home stay program differed from the other commercial home stay in the world. Home stay accommodation can create a scope to the local communities for active participation in tourism activities. Home stay accommodation might be a potential economic activity in the East Coast Economic Region (ECER). The study examined the potentialities of home stay accommodation for tourism development in ECER. The aim of the study was to analyze the overall situations of home stay accommodation in ECER from the perception of operators. Approach: The data of this study perceived from both the primary and secondary sources. A structured questionnaire had been used for data collection. In 2006, home stay accommodation was remaining 31 villages and in the year 2008 it spreads in 38 villages of ECER. Within this period, there were 482 and 648 home stay operators in this region. The necessary requirements for home stay operations are located; basic facilities; hygiene; safety and security. Results: There were some potentialities are remaining in ECER for establishing home stay in this region. These were low charging, hospitality, motivation for young generation, women entrepreneurship, profitable investment, easy access and satisfactory income. Some initiatives such as government support, capacity building, develop facilities, appropriate act, Community involvement, loan facilities and infrastructure development might be taken for the home stay accommodations in ECER. Conclusion: Research initiatives, various services for customer satisfaction, sustainable marketing and proper policy in management had been considered for home stay development in ECER. Home stay accommodations would be ensured the economic advancement in this region as well as sustainable regional development.
\end{abstract}

Key words: East Coast Economic Region (ECER), Malaysian Homestay Association (MHA), regional development, structured questionnaire, economic advancement

\section{INTRODUCTION}

Home stay is an accommodation system and economic activity in the tourism industry. It is popular with the tourists who want to interact with local culture, lifestyle, social system and people (LTSN, 2003). The important components of the home stay program are education, entertainment, enrichment, food, accommodation and hospitality (Levitt, 1986). Home Stay means to living place and it is one type of tourism product based on accommodation oriented. The improving, enhancing and promoting of home stay depends on local communities. This accommodation is ensuring their economic, social and cultural aspects with sustainable well beings (Chaiyatorn et al., 2010).

The main component of home stay is the cultural diversity of the local people which can attract the visitors (Din and Mapjabil, 2010). Social returns of home stay accommodation are essential for its success. The home stay program should be given emphasize on the emotional feelings of the local communities. It must be respectful of the local heritage, sense of place and social organizations (Beeton, 2006). When a large number of tourists are arriving in an area, then the

Corresponding Author: Md. Anowar Hossain Bhuiyan, Institute for Environment and Development (LESTARI),

University Kebangsaan Malaysia, 43600 UKM, Bangi, Darul Ehsan, Selangor, Malaysia

1085 
government and local people giving emphasize on home stay operation which increase the economic growth in this area (Gu and Wong, 2010).

The Malaysian tourism industry has been rising significantly in year by year. In the world rank Malaysia, stays in 31 st position with good transport infrastructure and service facilities (Mohebi and Rahim, 2010). The industry provides an important source of income generating and employment creation to the country. Tourism is the second largest foreign exchange earning source for the country after manufacturing (Bhuiyan et al., 2011). The industry provides an important source of income, employment and economic development to the country. In Malaysia, home stay accommodation mainly operates and organized by the Kampung (village) people. The home stay operators are developing Malay culture and activities in their accommodations. Necessary spaces, level of quality and security of houses are important elements for the home stay operation in Malaysia. The home stay program provides tourists multi ethnic life condition with cultural experiences and economic well beings for the local people (Liu, 2006). According to the Malaysian Home stay Association (MHA), foreign visitors from Japan, Australia and Korea while students of Malaysia are the important client for home stay accommodation (Kayat, 2007).

The Malaysian home stay program has announced officially as a tourism product in 1995. Home stay can be highlighted the rural lifestyle and culture of local communities. It has recognized a potential tourism product in the rural tourism master plan in 2001 (UNDP, 2003). The Malaysian home stay program differs from the other commercial home stay in the world. Here guests are living with the family members of home stay owner during their stay period. The operators' involves with the guests eating, cooking and other activities which exchange their culture and can learn from each other (Peterson, 2004).

The home stay owners have participated in the various programs of government to improve and develop the living standard of rural people. Again, they are working with the village's Development and Security Committee for the rural development. Home stay program main contribution is to develop the life standard and economic condition of the operators. It can attract potential visitors, who can gather their knowledge and experience by their visits. The home stay programs in Malaysia get huge support from government. The government has allocated required capital to the home stay operator for capacity building and empowerment. This allocation is largely provided to the lower socioeconomic groups (Din and Mapjabil, 2010).
Home stay accommodation is helpful for tourism development in a country or an area. Rural tourism, ecotourism and cultural tourism are facing accommodation problems at near the tourism destination. Home stay can solve the accommodation problem for this type's tourism. Rural and cultural tourism destinations have active participation of local people. On the other hand, ecotourism tries to decrease the environmental degradation with ensuring strong community participation in tourism activities. Home stay accommodation can create a scope to the local communities for active participation in tourism activities. The network development between local government and community is necessary to understand and adjust knowledge regarding tourism activities (Saeng-Ngam et al., 2009).

Three states of Malaysia- Kelantan, Terengganu, Pahang and the district of Mersing in Johor consisting of the East Coast Economic Region (ECER). The Malaysian government has established the economic region for the proper development of this area. This region represents the half of the land area in Peninsular Malaysia and one- seventh population of Malaysia. There are some economic and social backwardness situations are remaining in this region rather than other states of Malaysia. These are low incomes, unemployment, poverty, low urbanization, insufficient infrastructure development and low level of investment. This region is full of natural resources, unspools beauties, beaches and cultural attractions. Tourism activities may be developed in this region on the basis of these attractions and natural resources. Tourism has been an important economic tool in the region, attracting both domestic and foreign tourists to the region's charming natural and cultural attractions. Most of the tourism attractions of the region are situated in the rural and non urban areas. Home stay accommodation may be a potential economic activity in ECER. This accommodation program should emphasize on local custom and cultural practices, to be attract the tourists as well as to create authentic interest and commitment among the local youth in ECER (ECER, 2008). Local people of this region can be participating in home stay for their economic advancement which ensures the economic development in this region. The present study examines the potentialities of home stay accommodation for tourism development in ECER. The aim of the study is analyzing the overall situations of home stay accommodation in ECER from the perception of operators.

\section{MATERIALS AND METHODS}

Data attainment: The data of this study have perceived from both the primary and secondary sources. 
Am. J. Applied Sci., 9 (7): 1085-1090, 2012

Table 1: Domestic tourists to the home stay accommodation in Malaysia, 2006-2008

\begin{tabular}{llll}
\hline State/ District & 2006 & 2007 & 2008 \\
\hline Perlis & NA & 390 & 1,286 \\
Kedah & 1,821 & 3,804 & 6,242 \\
Langkawi & 87 & 290 & 697 \\
Penang & NA & NA & 1,064 \\
Perak & NA & 2,200 & 1,750 \\
Selangor & 6,065 & 15,361 & 10,242 \\
Melaka & 476 & 3,434 & 5,275 \\
N. Sembilan & 7,335 & 11,283 & 10,104 \\
Johor & 2,712 & 5,970 & 17,704 \\
Kelantan & NA & 390 & 705 \\
Terengganu & 1,016 & 1,338 & 446 \\
Pahang & NA & 2,721 & 2,052 \\
Sarawak & 1,978 & 414 & 8,235 \\
Sabah & 3,017 & 3,068 & 2,214 \\
Labuan & NA & 392 & 400 \\
Total & 24,507 & 51,055 & 68,416 \\
\hline Source: Tourism Services Division MT $(2009)$ NA- Not Available
\end{tabular}

For collecting primary data, a total of 10 home stay owners is selected from the state of Terengganu in ECER. A structured questionnaire has been used for data collection. A total of 17 questions is included in the questionnaire. About 11 items of the questionnaire are open-ended and rests on others are close-ended. In order to obtain the reliable secondary data different journals, books, annual reports, papers of different agencies have consulted carefully. The major manipulations for acquiring data are home stay accommodation in East Coast Economic Region (ECER), Malaysia. The outcomes of the study are demonstrated from the analysis of collecting data.

Table 1 reveals the domestic tourists to the home stay accommodation in Malaysia for the period of 20062008. The numbers of domestic tourists in home stay accommodation increase year by year in Malaysia. The home stay accommodations attract 24,507, 51,055 and 68,416 domestic tourists in the year 2006, 2007 and 2008 respectively. Selangor, Negari Sembilan and Johor attract highest domestic tourists in home stay accommodations. Pahang attracts highest numbers of domestic tourists in the home stays among the ECER states.

Table 2 shows the foreign tourists to the home stay accommodation in Malaysia for the period of 20062008. A total of $14,458,21,368$ and 23,117 foreign tourists attracts by the year 2006, 2007 and 2008 respectively in Malaysia. Among the states, Selangor and Johor attract the highest numbers of foreign tourists. Pahang attracts highest numbers of foreign tourists in the home stays among the ECER states.

Table 3 represents the home stay accommodations in villages and operators for the period of 2006-2008 in Malaysia. The numbers of villages and operators in home stay accommodations increase year by year in Malaysia.
Table 2: Foreign tourists to the home stay accommodation in Malaysia, 2006-2008

\begin{tabular}{lccr}
\hline State/ District & 2006 & 2007 & 2008 \\
\hline Perlis & NA & 110 & 55 \\
Kedah & 128 & 213 & 377 \\
Langkawi & 20 & 49 & 290 \\
Penang & NA & NA & 197 \\
Perak & NA & 50 & 370 \\
Selangor & 3,690 & 5,561 & 7,301 \\
Melaka & 1,169 & 799 & 1,425 \\
N. Sembilan & 825 & 3,816 & 2,939 \\
Johor & 4,420 & 6,275 & 4,635 \\
Kelantan & NA & 45 & 170 \\
Terengganu & 119 & 194 & 306 \\
Pahang & NA & 1,194 & 450 \\
Sarawak & 2,090 & 186 & 2,245 \\
Sabah & 1,997 & 2,707 & 2,295 \\
Labuan & NA & 169 & 62 \\
Total & 14,458 & 21,368 & 23,117 \\
\hline Source: Tourism & Services Division MT $(2009)$ NA- Not Available
\end{tabular}

Table 3: Home stay accommodations in villages and operators, 2006-2008

\begin{tabular}{|c|c|c|c|c|c|c|}
\hline \multirow[b]{2}{*}{ Year } & \multicolumn{2}{|l|}{2006} & \multicolumn{2}{|l|}{2007} & \multicolumn{2}{|l|}{2008} \\
\hline & Village & Operators & Village & Operators & Village & Operators \\
\hline Perlis & 1 & 12 & 1 & 12 & 2 & 34 \\
\hline Kedah & 2 & 51 & 3 & 94 & 6 & 106 \\
\hline Langkawi & 4 & 96 & 4 & 97 & 4 & 94 \\
\hline Penang & 8 & 116 & 9 & 200 & 9 & 202 \\
\hline Perak & 7 & 117 & 8 & 154 & 6 & 178 \\
\hline Selangor & 4 & 454 & 16 & 371 & 16 & 535 \\
\hline Melaka & 5 & 97 & 5 & 112 & 4 & 103 \\
\hline N. Sembilan & 5 & 120 & 6 & 194 & 8 & 234 \\
\hline Johor & 15 & 42 & 15 & 246 & 15 & 435 \\
\hline Kelantan & 6 & 123 & 6 & 125 & 8 & 163 \\
\hline Terengganu & 5 & 82 & 5 & 149 & 7 & 149 \\
\hline Pahang & 20 & 277 & 22 & 383 & 23 & 336 \\
\hline Sarawak & 12 & 144 & 14 & 152 & 16 & 172 \\
\hline Sabah & 15 & 188 & 18 & 203 & 19 & 228 \\
\hline Labuan & 7 & 22 & 3 & 41 & 3 & 65 \\
\hline Total & 105 & 1563 & 135 & 2533 & 146 & 3034 \\
\hline
\end{tabular}

Source: Tourism Services Division, MT (2009)

There are 105, 135 and 146 villages facilitate home stay accommodations in Malaysia for the year 2006, 2007 and 2008 respectively. On the other hand, there are 1563, 2533 and 3034 home stay operators in Malaysia for the year 2006, 2007 and 2008 respectively.

\section{RESULTS}

Table 4 demonstrates the Demographic information of home stay owners in the study. The respondents' age is 40-60 year old range. Most of the respondents are male and married. On the other hand, only three respondents have primary level education and others have either secondary or college level education.

Table 5 represents the profile of home stay owners in terms of household and home stay activities. The household members of the home stay owners are 3-7 persons. Most of the home stays have 3-15 rooms for the rental. Their initial investments are 30,000-90,000 Ringgit. The expected times of break-even in their investments are two to three years. 
Am. J. Applied Sci., 9 (7): 1085-1090, 2012

Table 4: Demographic information of home stay owners

\begin{tabular}{lllll}
\hline $\begin{array}{l}\text { Owner's } \\
\text { No. }\end{array}$ & Age & Sex & Marital status & Education level \\
\hline 1 & 55 & Male & Married & Secondary \\
2 & 71 & Female & Married & Primary \\
3 & 57 & Male & Married & Primary \\
4 & 46 & Male & Single & Secondary \\
5 & 58 & Male & Married & Secondary \\
6 & 44 & Female & Married & College \\
7 & 48 & Male & Married & Secondary \\
8 & 47 & Male & Married & College \\
9 & 43 & Females & Married & College \\
10 & 53 & Male & Married & Secondary \\
\hline
\end{tabular}

Source: Survey primary data, 2011

Table 5: Profile of home stay owners

\begin{tabular}{llccc}
\hline $\begin{array}{l}\text { Owner's } \\
\text { No. }\end{array}$ & $\begin{array}{l}\text { Household } \\
\text { members }\end{array}$ & $\begin{array}{l}\text { Rooms } \\
\text { for rent }\end{array}$ & $\begin{array}{l}\text { Initial } \\
\text { Investment (RM) }\end{array}$ & $\begin{array}{l}\text { Expected time of } \\
\text { break-even (Year) }\end{array}$ \\
\hline 1 & 7 & 7 & 60,000 & 2.5 \\
2 & 3 & 4 & 30,000 & 2.0 \\
3 & 5 & 15 & 80,000 & 3.0 \\
4 & 6 & 2 & 40,000 & 3.0 \\
5 & 6 & 7 & 90,000 & 3.0 \\
6 & 5 & 6 & 60,000 & 3.0 \\
7 & 4 & 5 & 70,000 & 2.5 \\
8 & 4 & 3 & 50,000 & 4.0 \\
9 & 5 & 4 & 60,000 & 2.0 \\
10 & 6 & 7 & 80,000 & 3.0 \\
\multicolumn{5}{l}{} \\
\multicolumn{5}{l}{}
\end{tabular}

Table 6: Profile of home stay

\begin{tabular}{lllll}
\hline $\begin{array}{l}\text { Owner's } \\
\text { No. }\end{array}$ & $\begin{array}{l}\text { Established home } \\
\text { stay (year) }\end{array}$ & $\begin{array}{l}\text { Managed and } \\
\text { operating home stay }\end{array}$ & $\begin{array}{l}\text { Employee in } \\
\text { home stay }\end{array}$ & $\begin{array}{l}\text { Receive } \\
\text { training }\end{array}$ \\
\hline 1 & 5 & Family members & 2 & No \\
2 & 4 & Employees & - & Yes \\
3 & 2 & Family members & - & No \\
4 & 4 & Family members & - & No \\
5 & 2 & Family members & - & No \\
6 & 4 & Family members & 2 & Yes \\
7 & 3 & Family members & 1 & Yes \\
8 & 4 & Family members & - & Yes \\
9 & 3 & Family members & 1 & Yes \\
10 & 5 & Family members & 2 & No \\
\hline
\end{tabular}

Source: Survey primary data, 2011

Table 7: Investments and revenues of home stay owners

\begin{tabular}{lllll}
\hline $\begin{array}{l}\text { Owner's } \\
\text { No. }\end{array}$ & $\begin{array}{l}\text { Monthly living } \\
\text { expenses (RM) }\end{array}$ & $\begin{array}{l}\text { Monthly } \\
\text { income (RM) }\end{array}$ & $\begin{array}{l}\text { Targeted annual } \\
\text { revenue (RM) }\end{array}$ & $\begin{array}{l}\text { Level of } \\
\text { satisfaction }\end{array}$ \\
\hline 1 & 1500 & 2000 & 32,000 & Dissatisfied \\
2 & 1000 & 1200 & 20,000 & Dissatisfied \\
3 & 1500 & 2000 & 36,000 & Dissatisfied \\
4 & 2000 & 600 & 10,000 & Satisfied \\
5 & 2000 & 1800 & 35,000 & Satisfied \\
6 & 1700 & 1200 & 20,000 & Satisfied \\
7 & 1400 & 1700 & 30,000 & Satisfied \\
8 & 1400 & 1200 & 15,000 & Satisfied \\
9 & 1600 & 1400 & 25,000 & Satisfied \\
10 & 1800 & 1500 & 30,000 & Satisfied \\
\hline
\end{tabular}

Source: Survey primary data, 2011

Table 6 reveals the profile of home stay in terms of management and operation. The maximum amount of home stay in this research was established in three to five years ago and managed by family members. Half of the home stays have appointed employee and the owners have received training for operating their activities.
Table 7 shows the investments and revenues of home stay owners. The respondents' monthly living expenses are within 1000-2000 Ringgit. Their monthly incomes from home stay are up to 2000 Ringgit. The home stays targeted annual revenue is $10,000-36,000$ Ringgit. Most of the respondents are satisfied with their income from home stay operation.

\section{DISCUSSION}

Home stay accommodations have increased in ECER year by year. In 2006, home stay accommodation was remaining 31 villages and in the year 2008 it spreads in 38 villages of ECER. Within this period, there were 482 and 648 home stay operators in this region (Table 3). According to the MT (2009), the necessary requirements for home stay operations are as follows.

Locations: The home stay must be situated in a suitable location for easy transportation and accessibilities. The areas of home stay keep free from pollution and promote the lifestyle of Malaysian culture.

Basic facilities: Proper and separate spaces are needed for home stay accommodation. These accommodations have given emphasize to the comfort of tourists, including facilities such as dining space, living rooms and toilets.

Hygiene: The home stay accommodations should be clean and free from pollution. Good toilets and drainage systems are needed to be in home stay for avoiding bad smell.

Safety and security: The tourists' insurance coverage is required for the home stay operation. Moreover, safety steps like fire protection facilities to be arranged by the home stay operators.

There are some potentialities are remaining in ECER for establishing home stay in this region which should be helpful in tourism development. These are,

Low charge: The accommodation, meal and other charges of home stay are cheaper than other accommodation facilities in ECER. The guests are normally spent RM60 to RM120 in a day for their all activities.

Hospitality: The guests of home stay get warm hospitality from the operators in ECER. The guests are becoming actually guests of the whole village areas.

Motivation for young generation: Home stay program build up confidence, patriotism and leadership among 
the young generation. The young generation learns about collaboration by working with the visitors' of home stay accommodation.

Women entrepreneurship: Home stay program is helpful for the women entrepreneurs in the rural areas. It provides new jobs and business opportunities to the women using their local resources. They can operate a small business, traditional food production and homemade cooking on the basis of the home stay program.

Easy access: Home stay accommodations are usually situated near the tourism attractions in ECER. If the visitors are staying in the home stay, they can enjoy easy access in the tourism attractions.

Profitable investment: Home stay operators can withdraw their investment of home stay accommodations within a short period. The present study shows that the expected timing of break-even in their investments are two to three years.

Satisfactory income: Home stay accommodation gives profitable income to the operator. The present study reveals that most of the operators are satisfied with their income from home stay accommodations.

Recommendation: The following initiatives may be taken for the home stay accommodations in ECER.

Government support: The home stay operators need proper training facilities and proper support of government for their business. If they have got sufficient support for home stay, it can play vital role in the rural economy.

Capacity building: Capacity assessment is very important for the home stay operations. Home stay accommodation is examined capacity building assessment for the rural development.

Develop facilities: Home stay operators can increase their facilities to attract more tourists. Some development program such as located near the main road, separate bedrooms and toilets for the guests, proper security and high standard of cleanliness may be helpful for home stay operation.

Appropriate act: An act should be passed to properly promote and develop the home stay program. Some entrepreneurs operate this business without proper licenses and certifications. They cannot ensure adequate facilities for the visitors. A policy needs to fulfill the criteria of home stay and properly operate this.

Community involvement: The success of home stay operation depends on community involvement and support towards this program. The home stay owners get opportunities, ability, power and incentives from the communities for their successful operation.

Loan facility: The government and non-government organization can allocate sufficient loan for home stay accommodation in ECER. They should be allocated this facility to the operators with reasonable terms and condition.

Infrastructure development: Most of the home stays in ECER are situated in rural and non urban areas. The infrastructure facilities in these areas must be developed for attracting the tourists.

\section{CONCLUSION}

East Coast Economic Region (ECER) is ranked in backward position in terms of national development rather than other parts of Malaysia. The national GDP and investment rate also lower in the region. The Malaysian government has taken several initiatives for economic enhancement of this region by tourism development. Home stay accommodation can be one of the major activities for tourism development in this region. The local people of this region will be benefited economically, socially and culturally by this accommodation. The development of home stay may be occurring by the joint efforts of the Tourism Ministry, ECER Development Council, Malaysian Homestay Association (MHA) and local investors. Again, Government support must be essential for suitable development of this accommodation. Research initiatives, various services for customer satisfaction, sustainable marketing and proper policy in management have been considered for home stay development in ECER. Finally, home stay accommodations will be ensured the economic advancement in this region as well as sustainable regional development.

\section{ACKNOWLEDGEMENT}

Financial assistance provided by the Arus Perdana (AP) Research Grant, Institute for Environment and Development, University Kebangsaan Malaysia (Ref. No.UKM-AP-PLW-04-2010) headed by Prof Chamhuri Siwar is gratefully acknowledged. 


\section{REFERENCES}

Beeton, S., 2006. Community Development Through Tourism. 1st Edn., Landlink Press, Collingwood, ISBN-10: 064309878X, pp: 256.

Bhuiyan, M.A.H., C. Siwar, S.M. Ismail and R. Islam, 2011. The role of government in ecotourism development: Focusing on east coast economic regions. J. Soc. Sci., 7: 557-564. DOI: 10.3844/jssp.2011.557.564

Chaiyatorn, S., P. Kaoses and P. Thitphat, 2010. The developmental model of cultural tourism home stay of the Lao Vieng and Lao song ethnic groups in the central region of Thailand. J. Soc. Sci., 6: 130-132. DOI: $10.3844 /$ jssp.2010.130.132

Din, A.K.H. and J. Mapjabil, 2010. Tourism Research in Malaysia: What, Which Way and so What? 1st Edn., Universiti Utara Malaysia Press, Sintok, ISBN-10: 9675311568, pp: 365.

ECER, 2008. East Coast Economic Region Development Council. Kuala Lumpur.

Gu, M. and P.P. Wong, 2010. Development of coastal tourism and Homestays on Dachangshan Dao, Liaoning Province, North East China, National University of Singapore.

Kayat, K., 2007. Customer orientation among rural home stay operators in Malaysia. ASEAN J. Hospitality Tourism, 6: 65-78.
Levitt, T., 1986. The Marketing Imagination. 1st Edn., Free Press, New York, ISBN-10: 0029191807, pp: 238.

Liu, A., 2006. Tourism in rural areas: Kedah, Malaysia. Tourism Manage., 27: 878-889. DOI: 10.1016/j.tour man.2005.05.007

LTSN, 2003. Resource Guide in: Homestay Accommodation Sector. Learning and Teacher Support Network.

Mohebi, M. and K.A. Rahim, 2010. Revenue determinants in tourism market. Am. J. Applied Sci., $\quad 7$ : 1593-1598. DOI: 10.3844/ajassp.2010.1593.1598

MT, 2009. Tourism services division. Ministry of Tourism, Malaysia.

Peterson, M., 2004. Home stays in Malaysia. Transitions Abroad Mag., 28: 56-57.

Saeng-Ngam, A., S. Chantachon and P. Ritthidet, 2009. The organization of cultural tourism by the community people in the region of Toong Kula Rong Hai. J. Soc. Sci., 5: 342-347. DOI: 10.3844/jssp.2009.342.347

UNDP, 2003. Rural tourism master plan for Malaysia. Ministry of Tourism, Kuala Lumpur, Malaysia. 